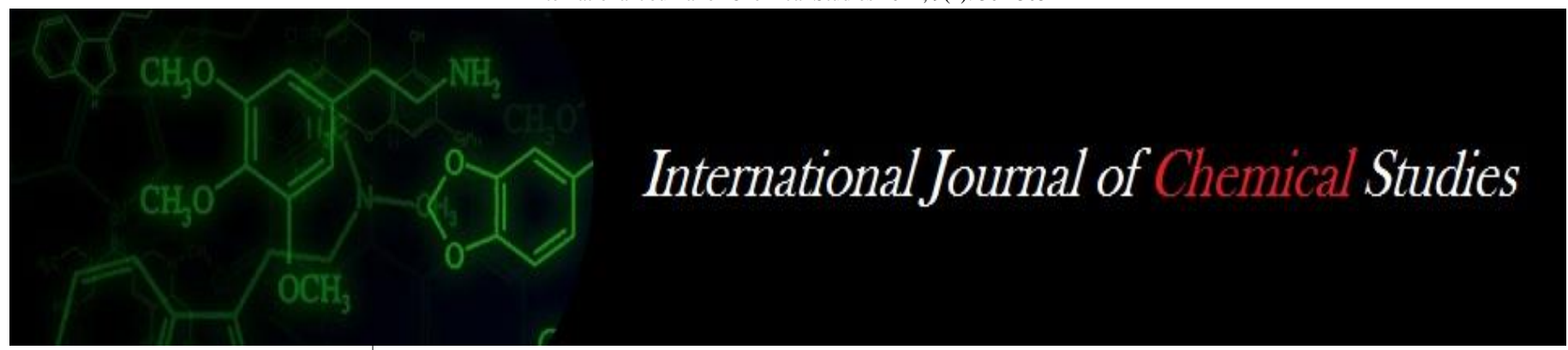

P-ISSN: 2349-8528

E-ISSN: 2321-4902

www.chemijournal.com

IJCS 2021; 9(1): 302-305

(C) 2021 IJCS

Received: 21-11-2020

Accepted: 30-12-2020

\section{Waghmare SS}

Department of Animal

Husbandry and Dairy Science,

College of Agriculture, Latur,

Maharashtra, Vasantrao Naik

Marathwada Krishi Vidyapeeth,

Parbhani, Maharashtra, India

\section{Ingale RR}

Department of Animal

Husbandry and Dairy Science,

College of Agriculture, Latur,

Maharashtra, Vasantrao Naik

Marathwada Krishi Vidyapeeth,

Parbhani, Maharashtra, India

\section{Patange SB}

Department of Animal

Husbandry and Dairy Science,

College of Agriculture, Latur,

Maharashtra, Vasantrao Naik

Marathwada Krishi Vidyapeeth,

Parbhani, Maharashtra, India

\section{Wavhal AS}

Department of Animal

Husbandry and Dairy Science,

College of Agriculture, Latur,

Maharashtra, Vasantrao Naik

Marathwada Krishi Vidyapeeth,

Parbhani, Maharashtra, India

Corresponding Author:

Patange SB

Department of Animal

Husbandry and Dairy Science,

College of Agriculture, Latur,

Maharashtra, Vasantrao Naik

Marathwada Krishi Vidyapeeth,

Parbhani, Maharashtra, India

\section{Studies on sensory properties of shrikhand by using ginger powder}

\author{
Waghmare SS, Ingale RR, Patange SB and Wavhal AS
}

DOI: https://doi.org/10.22271/chemi.2021.v9.i1d.11247

\begin{abstract}
Shrikhand is a semi-soft, sweetish sour, whole milk product prepared from lactic fermented curd, the curd is partially stained through a muslin cloth to remove the whey and thus produce a solid mass called chakka. Herbal sweet preparation is a new concept in dairy industry. Herbal such as ginger juice is being used in limited extent as a flavoring agent in tea by household, besides it has medicinal properties against cough, cold etc. and is used extensively in ayurvedic medicine. Ginger flavored shrikhand can be considered as herbal shrikhand looking to diversified benefits and medicinal value of ginger. It was thought to prepare shrikhand by incorporation of ginger powder. In the present study the shrikhand was prepared from buffalo milk using ginger powder at different level viz. 2 per cent $\left(\mathrm{T}_{1}\right), 4$ per cent $\left(\mathrm{T}_{2}\right), 6$ per cent $\left(\mathrm{T}_{3}\right), 8$ per cent $\left(\mathrm{T}_{4}\right)$ of chakka. This prepared shrikhand was compared with control shrikhand $\left(\mathrm{T}_{0}\right)$ i.e. without ginger powder. From the results of the present investigation, it may be concluded that ginger powder could be successfully utilized for preparation of shrikhand. Addition of ginger powder in shrikhand improved the sensory quality and acceptability of the product. Besides typical flavor, it also adds medicinal properties to the product.
\end{abstract}

Keywords: Chakka, Shrikhand, sensory, ginger

\section{Introduction}

Shrikhand is a semi-soft, sweetish sour, whole milk product prepared from lactic fermented curd, the curd is partially stained through a muslin cloth to remove the whey and thus produce a solid mass called chakka. The dish is very popular in Gujarat, Maharashtra and Karnataka. The shrikhand word is derived from the Sanskrit root 'shrikha rani' meaning good nourishing food having high protein and calorific value. Singh et al. (2015). Value. Singh et al. (2015) the keeping quality of shrikhand largely depends upon its initial micro flora like yeast, mould and other microorganisms. Under ambient condition $\left(30^{0} \mathrm{c}\right)$ it trends to spoil within 2-3 days. Under refrigerated condition $\left(5^{0} \mathrm{c}\right)$ it can be kept for 40 days for deterioration. So in order to increase the milk availability during lean periods summer months the shrikhand preparation is best under Indian condition. Herbal sweet preparation is a new concept in dairy industry.

Herbal such as ginger juice is being used in limited extent as a flavoring agent in tea by household, besides it has medicinal properties against cough, cold etc. and is used extensively in ayurvedic medicine. Ginger flavored shrikhand can be considered as herbal shrikhand looking to diversified benefits and medicinal value of ginger. It was thought to prepare shrikhand by incorporation of ginger powder. Recently herbal products either in the form of cosmetics or food has become more popular in the world market. Epidemiological data as well as in vitro studies strongly suggest that food containing phyto-chemical with anti-oxidation potential have strong protective effect against major disease risks including cancer and cardiovascular disease. (Kaur and Kapoor, 2002) ${ }^{[5]}$. Looking to the benefits of medicinal value of ginger the present research project entitled "studies on method of preparation of shrikhand by using ginger powder',

\section{Material and Methods}

Present investigation was undertaken to prepare shrikhand with ginger powder (Zingiber officinale L.). The research was conducted in Department of Animal Husbandry and Dairy Science, College of Agriculture Latur, Vasantrao Naik Marathwada Krishi Vidyapeeth, Parbhani. The materials used and method were adopted were as under. 
Fresh standardized milk used for product preparation Good quality dried ginger was purchased from the local market. It was grinded in powder form, then that powder was strained through fine sieve. Dahi culture was prepared in the Departmental laboratory

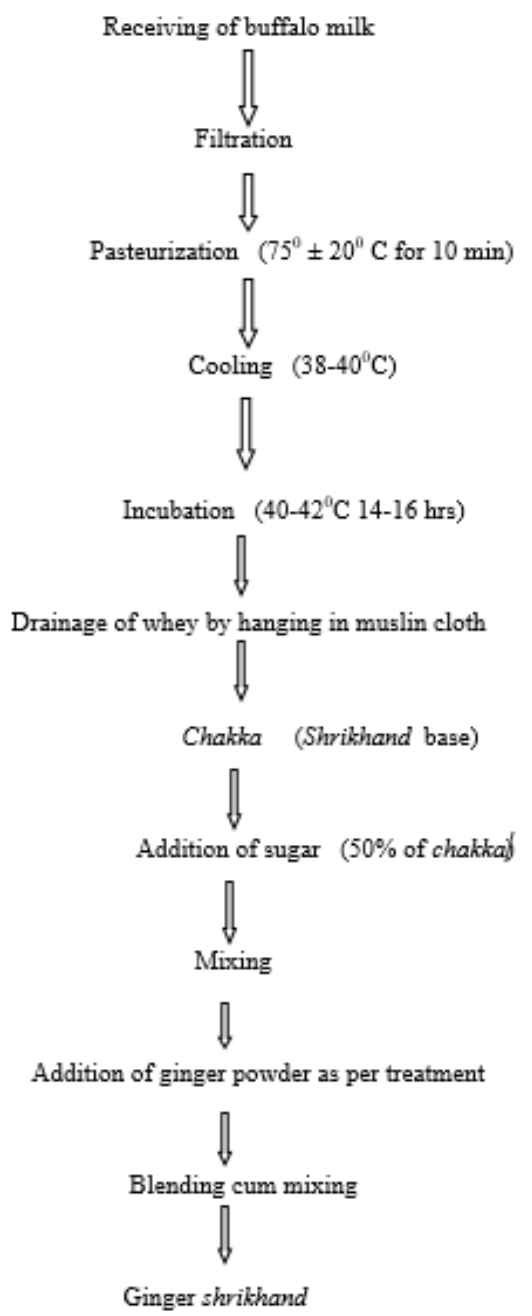

Fig 1: Preparation of shrikhand by using ginger powder

\section{Treatment Details}

The chakka and ginger powder will mixed (w/w) to prepare shrikhand in the following proportions.

$\begin{array}{ccc}\text { Treatment } & \text { Chakka } & \text { Ginger } \\ \mathrm{T}_{0} & 100 & 00 \\ \mathrm{~T}_{1} & 98 & 02 \\ \mathrm{~T}_{2} & 96 & 04 \\ \mathrm{~T}_{3} & 94 & 06 \\ \mathrm{~T}_{4} & 92 & 08\end{array}$

$\mathrm{T}_{0}$ - Pure control shrikhand.

$\mathrm{T}_{1}-98$ parts of shrikhand +2 parts of ginger powder.

$\mathrm{T}_{2}-96$ parts of shrikhand +4 parts of ginger powder.

$\mathrm{T}_{3}-94$ parts of shrikhand +6 parts of ginger powder.

$\mathrm{T}_{4}-92$ parts of shrikhand +8 parts of ginger powder

\section{Result and Discussion}

\section{Sensory evaluation of finished product}

The acceptability of the final product was measured in terms of sensory attributes such as, colour, flavour, consistency and taste using 9- point hedonic scale by a panel of five expert judges. The data so obtained were analyzed using Completely
Randomized Block Design (CRBD). The overall acceptability of the product was also worked out.

\section{Colour and Appearance}

Table 1: Score for colour and appearance of ginger shrikhand: (out of ' 9 ')

\begin{tabular}{|c|c|c|c|c|}
\hline Treatment & \multicolumn{3}{|c|}{ Replication } & Mean \\
\hline & I & II & III & \\
\hline $\mathrm{T}_{0}$ & 8.2 & 8.1 & 8.0 & $8.1^{\mathrm{c}}$ \\
\hline $\mathrm{T}_{1}$ & 8.4 & 8.2 & 8.4 & $8.3^{\mathrm{ab}}$ \\
\hline $\mathrm{T}_{2}$ & 8.5 & 8.6 & 8.4 & $8.5^{\mathrm{a}}$ \\
\hline $\mathrm{T}_{3}$ & 8.3 & 8.4 & 8.5 & $8.4^{\mathrm{a}}$ \\
\hline $\mathrm{T}_{4}$ & 8.1 & 8.2 & 8.3 & $8.2^{\mathrm{bc}}$ \\
\hline \multicolumn{4}{|c}{$\mathrm{SE}= \pm 0.0596 \mathrm{CD}$ at $5 \%=0.1878$} \\
\hline
\end{tabular}

It is revealed from the table 1 that the score for colour and appearance attribute ranged between 8.20 to 8.33 for $T_{4}$ to $T_{1}$ combination, respectively. Score recorded for this parameter was found i.e. 8.1, 8.3, 8.5, 8.4, and 8.2 for $\mathrm{T}_{0}, \mathrm{~T}_{1}, \mathrm{~T}_{2}, \mathrm{~T}_{3}$ and $\mathrm{T}_{4}$ respectively. Treatment $T_{2}$ and $T_{3}$ was similar to each other but treatment $T_{0}$ is significantly differ from treatment $T_{2}$ and $\mathrm{T}_{3}$. Among the levels of inclusion of ginger powder. The lowest score for colour and appearance was obtained at 8.1 which possessed more yellow appearance, unacceptable colour and liked by the evaluator. As far as the blends were concerned $\mathrm{T}_{2}$ combination had been preferred by the judges for colour and appearance than the other treatment combinations. The result recorded in present investigation for flavor score were comparable with findings of below mentioned research workers.

Daadrwal et al. (2005) [1] observed that the shrikhand prepared by incorporation of fruit pulp in milk as well as in chakka with regardto colour and appearance the product prepared by addition of $5 \%$ pulps in milk and $10 \%$ pulp in chakka were at per with the product prepared with milk alone. Salunke et.al (2006) observed that the prduct made by manufactures within the city $\mathrm{C}_{1}, \mathrm{C}_{2}$, and $\mathrm{C}_{4}$ were at par with each other with respect to colour and appearance scores, whereas for city $\mathrm{C}_{3}$ the score of shrikhand for different manufactures differed significantly.

\section{Flavour score}

Table 2: Flavour score for the ginger shrikhand

\begin{tabular}{|c|c|c|c|c|}
\hline Treatment & \multicolumn{3}{|c|}{ Replication } & Mean \\
\hline & I & II & III & \\
\hline $\mathrm{T}_{0}$ & 7.8 & 7.7 & 8.0 & $7.8^{\mathrm{a}}$ \\
\hline $\mathrm{T}_{1}$ & 8.0 & 8.0 & 7.3 & $7.7^{\mathrm{a}}$ \\
\hline $\mathrm{T}_{2}$ & 7.5 & 7.2 & 7.5 & $7.4^{\mathrm{ab}}$ \\
\hline $\mathrm{T}_{3}$ & 7.2 & 7.3 & 6.4 & $6.9^{\mathrm{b}}$ \\
\hline $\mathrm{T}_{4}$ & 7.3 & 7.4 & 7.6 & $7.4^{\mathrm{ab}}$ \\
\hline \multicolumn{4}{|c}{$\mathrm{SE}= \pm 0.1795 \mathrm{CD}$ @ 5\% $=0.5655$} \\
\hline
\end{tabular}

From table 2 resulted that the average score obtained for flavor of shrikhand by addition of ginger powder with different levels. The data regarding average score of shrikhand without addition of ginger powder $\left(\mathrm{T}_{0}\right)$ scored 7.8 followed by 7.7 and 7.4 at treatment $\mathrm{T}_{1}$ and $\mathrm{T}_{2}$, respectively. This increase may be attributed to characteristic ginger flavor to shrikhand. However, at higher level of ginger powder the score was reduced to 7.7 and 6.9 at treatment $T_{1}$ and $T_{3}$, respectively. Thus decrease in score may be due to strong pungent aroma and taste which was not liked by the judges. 
The perusal of data from Table 7 showed that the shrikhand prepared from $\mathrm{T}_{2}$ level recorded highest score for flavour (7.4) followed by $T_{1}$ (7.7). The sensory score increased up to $\mathrm{T}_{2}$ i.e. 10 per cent level of ginger powder and decreased simultaneously for $\mathrm{T}_{3}$ and $\mathrm{T}_{4}$. Lowest score was noticed for shrikhand blended with 6 per cent ginger powder (6.9). Dadarwal et.al (2005) ${ }^{[1]}$ observed that the scores for flavor were better with guava and sapota pulp added in milk as well as with banana and guava pulps directly added in chakka than the control.

\section{Sweetness score}

Table 3: Sweetness score for ginger shrikhand

\begin{tabular}{|c|c|c|c|c|}
\hline Treatment & \multicolumn{3}{|c|}{ Replication } & Mean \\
\hline & I & II & III & \\
\hline $\mathrm{T}_{0}$ & 8.1 & 8.0 & 8.1 & $8.07^{\mathrm{a}}$ \\
\hline $\mathrm{T}_{1}$ & 7.5 & 7.9 & 7.4 & $7.60^{\mathrm{ab}}$ \\
\hline $\mathrm{T}_{2}$ & 7.8 & 7.9 & 7.8 & $7.83^{\mathrm{a}}$ \\
\hline $\mathrm{T}_{3}$ & 6.3 & 6.7 & 7.0 & $6.67^{\mathrm{c}}$ \\
\hline $\mathrm{T}_{4}$ & 6.8 & 7.2 & 7.8 & $7.27^{\mathrm{b}}$ \\
\hline \multicolumn{4}{|c}{ S.E. $= \pm 0.1738$ C.D. at $5 \%=0.5476$} \\
\hline
\end{tabular}

It is revealed that table no. 3 means score for sweetness of ginger shrikhand $8.07,7.60,7.83,6.67$, and 7.27 for treatment $\mathrm{T}_{0}, \mathrm{~T}_{1}, \mathrm{~T}_{2}, \mathrm{~T}_{3}$ and $\mathrm{T}_{4}$ respectively. Treatment $\mathrm{T}_{1}, \mathrm{~T}_{2}$, and $\mathrm{T}_{4}$ were similar to each other, but treatment $T_{0}$ and $T_{3}$ is significantly differ from each other but treatment $\mathrm{T}_{2}$ consider as superior over rest of treatments which was comparable with control. The result recorded in present investigation for sweetness score were comparable with findings of below mentioned research workers.

Miyani et al. (1984) reported that 35-40 per cent moisture and 40 per cent sugar was highly preferable with respect to sensory profile and consistency of the product.

Patel et al. (1985) reported that 41 per cent sugar level in shrikhand produced most desirable characteristics in product.

\section{Body and texture score}

Table 4: Body and texture score for ginger shrikhand

\begin{tabular}{|c|c|c|c|c|}
\hline Treatment & \multicolumn{3}{|c|}{ Replication } & Mean \\
\hline & I & II & III & \\
\hline $\mathrm{T}_{0}$ & 8.3 & 8.0 & 7.6 & 7.97 \\
\hline $\mathrm{T}_{1}$ & 7.9 & 8.3 & 8.5 & 8.23 \\
\hline $\mathrm{T}_{2}$ & 7.8 & 8.2 & 8.5 & 8.17 \\
\hline $\mathrm{T}_{3}$ & 7.5 & 8.0 & 7.9 & 7.80 \\
\hline $\mathrm{T}_{4}$ & 7.3 & 7.3 & 7.8 & 7.47 \\
\hline \multicolumn{5}{|l}{ S.E. $= \pm 0.1813$ C. D. at 5\%=0.5713 } \\
\hline
\end{tabular}

It is observed from table no. 4 treatment $T_{0}, T_{1}, T_{2}$. But these treatments were significantly differing from treatment $\mathrm{T}_{3}$. The body and texture score for ginger shrikhand samples were low as compare to control. The $\mathrm{T}_{2}$ blend was comparatively preferred by judges as far as body and texture concerned. Treatment $T_{3}$ showed some grainy structure which was not preferred by judges. The result showed in present investigation of body and texture score were comparable with findings of below mentioned research workers.

Gavane et al. (2010) reported that, blending of maximum of 2 per cent of custard apple pulp had a positive appeal on the body and texture of shrikhand. Kumar et al. (2011) [6] observed mean body and texture scores decreased significantly with increasing level of apple pulp i.e. 6.52 to 7.20 .

\section{Overall acceptability}

Table 5: Overall acceptability of ginger shrikhand

\begin{tabular}{|c|c|c|c|c|c|}
\hline Treatment & \multicolumn{4}{|c|}{ Replication } & Mean \\
\hline & I & II & III & & \\
\hline $\mathrm{T}_{0}$ & 8.10 & 7.83 & 7.97 & 8.03 & 7.6 \\
\hline $\mathrm{T}_{1}$ & 8.33 & 7.77 & 8.23 & 7.60 & 7.8 \\
\hline $\mathrm{T}_{2}$ & 8.50 & 7.40 & 8.17 & 7.83 & 7.9 \\
\hline $\mathrm{T}_{3}$ & 8.40 & 6.97 & 7.80 & 6.67 & 7.4 \\
\hline $\mathrm{T}_{4}$ & 8.20 & 7.43 & 7.47 & 7.27 & 7.5 \\
\hline & $\mathrm{SE}=$ & $219 \mathrm{C}$ & $5 \%=$ & & \\
\hline
\end{tabular}

From table no. 5 resulted that the mean overall acceptability of ginger shrikhand for treatments $\mathrm{T}_{0}, \mathrm{~T}_{1}, \mathrm{~T}_{2}, \mathrm{~T}_{3}$ and $\mathrm{T}_{4}$ was 7.6, 7.8, 7.9, 7.4 and 7.5 respectively. Treatments $\mathrm{T}_{0}, \mathrm{~T}_{1}$ and $\mathrm{T}_{2}$ was found at par with each other whereas other treatment i.e. $\mathrm{T}_{3}$ and $\mathrm{T}_{4}$ significantly differ from $\mathrm{T}_{0}, \mathrm{~T}_{1}$ and $\mathrm{T}_{2}$. It was observed that treatment $\mathrm{T}_{2}$ was significantly superior. The lowest ovearall acceptability score i.e. 7.5 was found in treatment $\mathrm{T}_{4}$ which decreased colour and appearance, body and texture, flavour and sweetness hence overall acceptability score was less as compared to $\mathrm{T}_{2}$ treatment. Treatment $\mathrm{T}_{2}$ scored at higher point. These result were comparable with findings of following workers.

Daadarwal et al. (2005) ${ }^{[1]}$ observed overall acceptability of shrikhand prepared with $5 \%$ in milk before pasteurization and lactic fermentation or 10 per cent directly in chakka was comparable with the product prepared without fruit pulp.

Nigam et al. (2009) ${ }^{[10]}$ observed that the fresh shrikhand of good overall acceptability could be prepared from 30 per cent level of sugar and 20 per cent of papaya.

Narayanan et al. (2013) ${ }^{[11]}$ observed that the score for overall acceptability was highest in $\mathrm{T}_{2}$ (8.6) and lowest in $\mathrm{T}_{0}(8.0)$ and it was significantly affected due to blending of banana pulp at 20 per cent level.

From present study it can be concluded that the ginger powder is very well useful for enhancing sensory as well as medicinal properties for making shrikhand

\section{References}

1. Dadarwal R, Beniwal BS, Singh R. Process standardization for preparation of fruit flavoured shrikhand. J Food Sci. and Technol 2005;42(1):2226.

2. Desai HK, Gupta SK. Sensory evaluation of shrikhand. Dairy Guide 1986;8(12):33.

3. Gavhane PM. Studies on preparation of shrikhand blended with custard apple pulp, a new fermented milk product. Indian J Dairy Sci 2007;63(1):11-14.

4. Ghatak PK, Dutta S. Effect of admixing of cow and buffalo Ind. J Nutr. Dietet 1998;35(2):43.

5. Kaur C, Kapoor HC. Anti-oxidant activity and total phenolic content of some Asian vegetables. International Journal of Food Science and Technology 2002;37:153161.

6. Kumar S, Bhat ZF, Kumar P. Effect of apple pulp and Celosia argentea on the quality characteristics of shrikhand. American J of Food Technology 2011;6(9):817-826.

7. Merai M, Boghra VR, Sharma RS. Extraction of Antioxygenic principle from Tulsi leaves and their effect on oxidative stability of ghee. J Food Sci. Technol 2003;40(1):52-57.

8. Patel S, Prasanth S, Choudhary PL, Shau C. Technoeconomic feasibility of whey based mango herbal 
(Ginger) beverage. Indian J of Dairy Sci 2007;60(3):149155.

9. Salunke P, Hasmukh A, Patel, Thakar PN. Microbilogical quality of shrikhand sold in maharashtra state. J Dairying, food and H.S 2005;24(2):150-152.

10. Nigam N, Singh R, Upadhayay PK. Incorporation of chakka by papaya pulp in the manufacture of shrikhand. J Dairy Science, Foods and Home Sci 2009;28(2):115-118.

11. Narayanan R, Lingam J. Sensory analysis of banana blended shrikhand. African Journal of Agricultural Research 2013;8(44):5518-5521. 